\title{
Inhaltsverzeichnis/Table of Contents
}

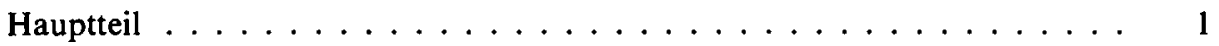

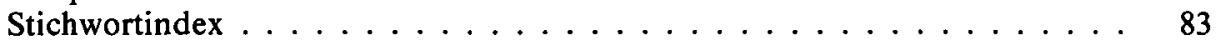

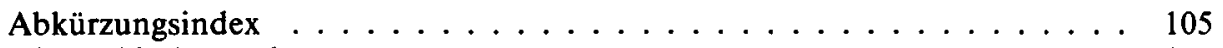

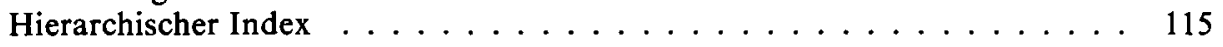

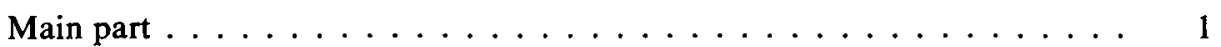

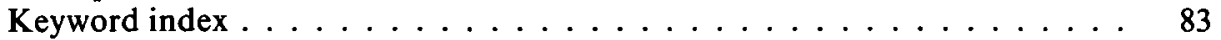

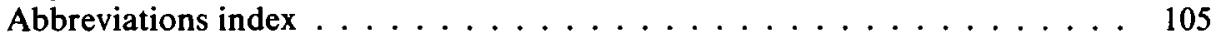

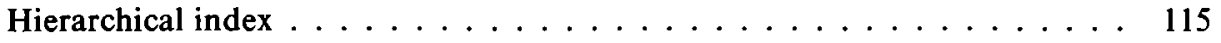

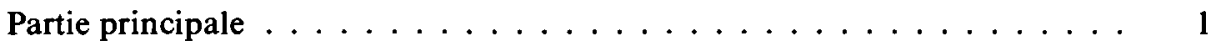

Index des mots-clés . . . . . . . . . . . . . . . . . . 83

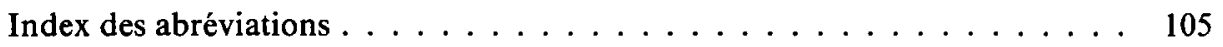

Index hiérarchique . . . . . . . . . . . . . . . 115

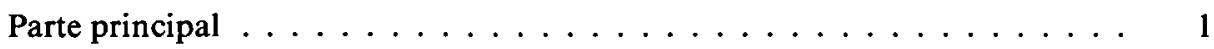

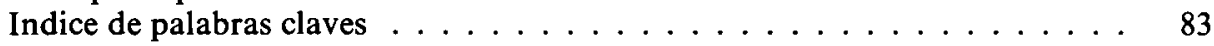

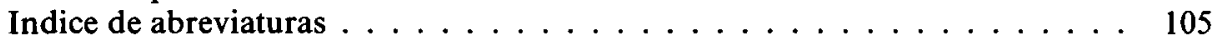

Indice jerárquico . . . . . . . . . . . . . . . . 115 
